\title{
A Contemporary View of Respiratory Syncytial Virus (RSV) Biology and Strain-Specific Differences
}

\author{
Mansi C. Pandya, Sean M. Callahan, Kyryll G. Savchenko and Christopher C. Stobart * \\ Department of Biological Sciences, Butler University, Indianapolis, IN 46208, USA; \\ mpandya@butler.edu (M.C.P.); smcallah@butler.edu (S.M.C.); ksavchen@butler.edu (K.G.S.) \\ * Correspondence: cstobart@butler.edu
}

Received: 28 March 2019; Accepted: 4 May 2019; Published: 21 May 2019

check for updates

\begin{abstract}
Respiratory syncytial virus (RSV) is a human respiratory pathogen which remains a leading viral cause of hospitalizations and mortality among infants in their first year of life. Here, we review the biology of RSV, the primary laboratory isolates or strains which have been used to best characterize the virus since its discovery in 1956, and discuss the implications for genetic and functional variations between the established laboratory strains and the recently identified clinical isolates.
\end{abstract}

Keywords: respiratory syncytial virus; RSV; strain-specific differences; viral evolution

\section{An Overview of RSV Biology}

\subsection{RSV Disease and Vaccines}

Respiratory syncytial virus (RSV) is a human respiratory virus that is responsible for the majority of acute lower respiratory tract infections in infants worldwide [1]. In addition, it continues to be commonly associated with lower respiratory infections and mortality among the elderly and in individuals with compromised immune states [2-6]. In 2015, an estimated 33.1 million cases of acute lower respiratory infections that occurred worldwide were associated with RSV [7]. Of those cases identified, approximately $10 \%$ were associated with hospitalization and $0.4 \%$ resulted in mortality. Although RSV infections occur regularly in healthy infants with no predisposing factors, conditions associated with enhanced susceptibility for RSV disease include premature birth, lack of initial infection, lack of or limited levels of maternal antibodies for protection against RSV, the presence of certain genetic predisposing traits, and/or the presence of cardiopulmonary disease [8-13]. Despite a high global burden of disease being attributable to RSV, there remains no commercially-available vaccines for RSV.

The World Health Organization (WHO) has identified RSV as a primary target for future vaccine development and has begun to establish standards for comparison. While many existing vaccines target a single primary population, the development of vaccines for RSV will likely need to target three distinct populations: Young infants (within the first three to six months of life), older infants and toddlers, and the elderly [2]. Numerous vaccine approaches are currently being explored to address one or more of these target populations, including live-attenuated, chimeric, vector-based, particle-based, subunit, and monoclonal antibody-based vaccine platforms [2]. The continued study of existing and developing strains of RSV will be essential to the future development of RSV vaccines, in order to understand the evolution of the virus and any potential changes in antigenicity that may arise.

\subsection{RSV Genome}

RSV belongs to the order Mononegavirales and family Pneumoviridae. It is an enveloped virus with a non-segmented, negative-sense RNA genome (-ssRNA) that is approximately $15.2 \mathrm{~kb}$ in length [13]. 
The genomic organization of RSV consists of 10 genes which collectively encode 11 proteins (Figure 1). RSV forms filamentous enveloped virions that are primarily covered in the attachment $(G)$ and fusion (F) glycoproteins, with a lesser amount of integrated pentameric small hydrophobic (SH) proteins within the envelope structure $[13,14]$. RSV F and G (see below) are responsible for mediating viral attachment and entry into cell hosts. Directly beneath the envelope, the viral matrix $(\mathrm{M})$ protein plays a key role in the assembly and stability of virion structures [13,15]. Within the virion are the nucleoprotein $(\mathrm{N})$, phosphoprotein $(\mathrm{P})$, and RNA-dependent RNA polymerase $(\mathrm{L})$, which protect the viral genome and mediate replication, along with a transcription processivity factor (M2-1) [13]. The two most common reverse genetics systems, which each employ the A2 strain genetic background, necessitate co-expression of these four viral proteins with a full-length antigenomic construct for infectious clone assembly $[15,16]$. In addition to the aforementioned structural genes and replicative machinery, RSV also produces two nonstructural proteins (NS1 and NS2), which have been shown to suppress innate immune signaling and antagonize apoptotic pathways [17-20].

\section{RSV A2 (15.2 kb)}
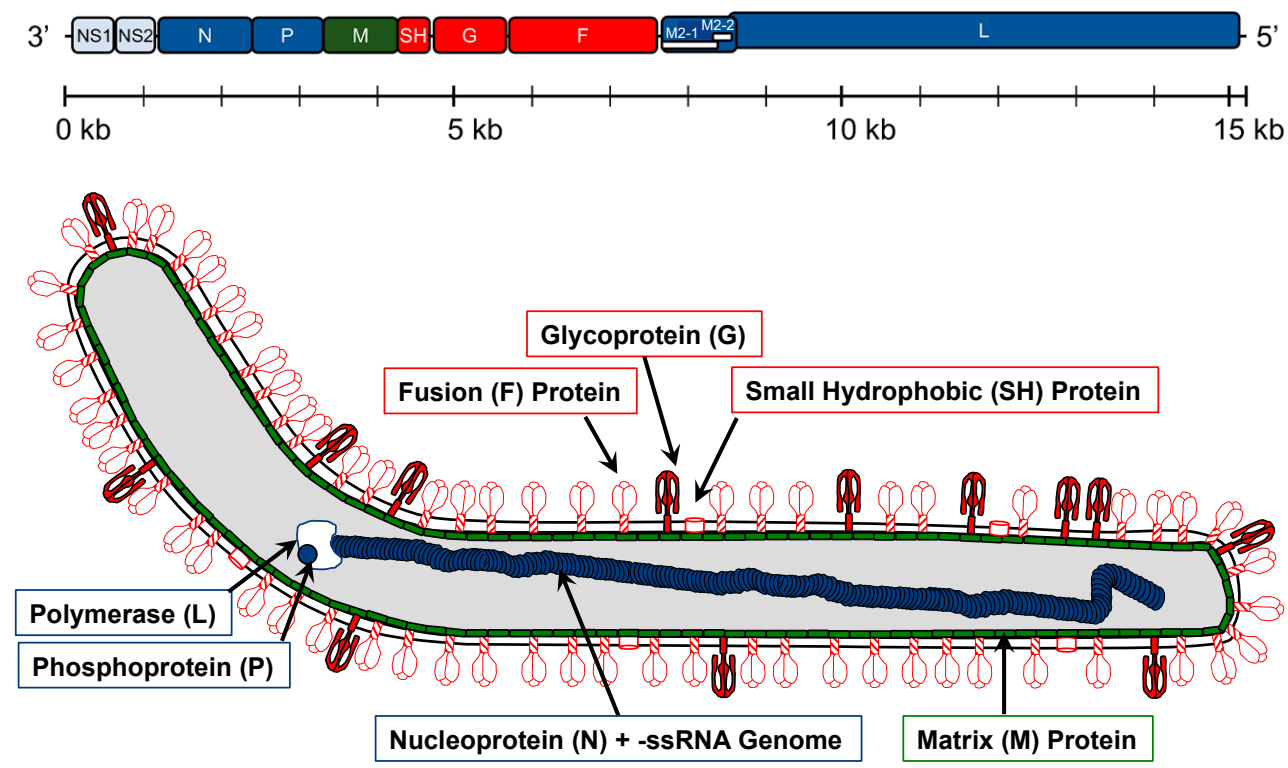

Figure 1. The genomic organization and virion structure of respiratory syncytial virus (RSV) strain A2 are shown with each of the 10 genes color-coded based on their relative functions: Immunomodulatory (light blue), envelope structure (green), surface structures for attachment and entry (red), and replication and genomic stability (dark blue). A size scale is provided with $1 \mathrm{~kb}$ gradations for evaluation of gene size. NS1/NS2, nonstructural protein 1/2; N, nucleocapsid; P, phosphoprotein; M, matrix; SH, small hydrophobic glycoprotein; G, attachment glycoprotein; F, fusion glycoprotein; L, large polymerase protein (RdRP).

\subsection{RSV Antigenicity and Infectivity}

RSV G and F are arguably the most well-studied proteins of the virus due to their critical roles in mediating attachment and fusion, respectively, as well as being responsible for inducing the majority of neutralizing antibodies in vivo [21-24]. RSV G is produced in membrane-bound and secreted forms during infection [25-28]. The membrane-bound form of RSV G is heavily glycosylated and exhibits two highly variable mucin-like regions and a central conserved region [29-32]. Overall, RSV G exhibits the most variable RSV gene sequence and has been used in the characterization of virus evolution and to establish genetic variants of circulating RSV [33]. While several host proteins have been identified as possible targets of RSV attachment in a wide range of cells, including heparin sulfate, surfactant protein A (SP-A), the fractalkine receptor (CX3CR1), and annexin II, it remains unclear what the primary host target for RSV G-mediated attachment is during infection in the human airway 
epithelium [34-39]. This initial interaction between RSV G and the host cell facilitates and likely aids in the engagement of RSV F to drive fusion between the viral envelope and host membrane [40]. During fusion, RSV F undergoes a dynamic conformational change from a metastable pre-fusion trimer to a stable post-fusion state [14,33,41,42]. While several host receptors for $\mathrm{F}$ attachment have been proposed, including nucleolin and the epidermal growth factor receptor (EGFR), the possible portals of RSV entry and the potential receptors for host fusion remain unclear [43-45]. Studies evaluating neutralizing antibodies of RSV F have identified several neutralizing sites, with the most potent neutralizing antibodies being associated with the binding of the prefusion conformational state of RSV F $[24,41,46]$. Subsequently, most current vaccine design efforts are focused on optimizing RSV F as a platform for inducing immunologic protection [2,47].

\subsection{RSV Genetic Diversity}

Traditionally, RSV is classified into two distinct groups or subtypes, RSV-A and RSV-B, which diverged approximately 350 years ago and are based on antigenic and sequence-based variations predominately associated with RSV G [48-51]. RSV exhibits seasonality with multiple genotypes, often in co-circulation with a dominance shift between RSV-A and RSV-B types every one to two years [52]. Within each of these two groups, several genotypes have been identified and described [49,50,53,54]. Recently, several unique genetic modifications in RSV G have been identified, which include a 72-nucleotide duplication (referred to as the ON genotype) associated with RSV-A types and a 60-nucleotide duplication (referred to as the BA genotype) associated with RSV-B types [53,55-57]. In the cases of each of these two new genotypes, they have rapidly become the predominant forms found in circulation worldwide and appear to increase in vitro viral fitness and attachment [58]. Furthermore, variations in RSV-A and RSV-B over time appear to correlate with the induction of anti-G monoclonal antibodies that recognize the primary epitopes, thus indicating immune-driven RSV evolution [59].

\section{Common Laboratory Strains of RSV}

Since its initial isolation from a chimpanzee in 1956 during an outbreak of coryza in a colony of animals and subsequent discovery in humans shortly after, most research on RSV has centered on the use of a limited number of historical isolates [60-62]. These prototypic "laboratory strains", while playing critical roles for identifying the key functions of viral proteins and the general virology of RSV infection, have shown in limited studies to exhibit subtle to significant differences in cytopathology, antigenicity, and pathogenicity, both in vitro and in vivo, when compared to other laboratory strains and clinical isolates. In this section, we will review the origins, general biology, and use of several common prototypic laboratory strains.

\subsection{RSV Long}

The RSV Long strain was first isolated by Robert Chanock from a child with bronchopneumonia in 1956 and was subsequently passaged 11 to 13 times in HEp-2 cells [62]. As the "first" prototypic strain, the Long strain was used extensively in the 1960s and 1970s to characterize the initial physical properties of the virus, antigenic variations between RSV isolates, pathophysiology, and epidemiology of RSV disease [60,63-70]. The RSV Long strain has also played an important role in the establishment of early animal models of RSV infection in vivo, including mice, ferrets, and cotton rats [71-73]. Although existing platforms using the genetic background of A2 had been available, in 2014, the first reverse genetics platform based on the Long genetic background was developed [74].

An early study in 1963 that compared the antigenic responses to strains Long and $\mathrm{CH}-18537$ (described below) was pivotal in suggesting that antigenically distinct strains of RSV exist [66]. Later studies would classify these strains into subtypes (groups) A and B, respectively, due in large part to the antigenic differences in the attachment glycoprotein G [48,75]. Along with strain A2 (described below), the Long strain continues to be recognized as a prototypic group (or subtype) A virus and is regularly used in comparative studies of antigenicity and neutralization [76,77]. 


\section{2. $R S V A 2$}

RSV strain A2 was first isolated in 1961 from the lower respiratory tract of an infant in Melbourne, Australia [78]. Since its initial isolation, RSV A2 has been established as the prototypic A strain for the study of RSV and remains the most common platform for the development of RSV live-attenuated vaccine candidates.

Although not recapitulating human disease, numerous studies have employed the A2 strain to elucidate and better characterize the immune responses to RSV in both mice and cotton rats [63,79-81]. In several common cell culture lines for the propagation and study of RSV (HEp-2, Vero, A549 cells) and in airway epithelial cultures, RSV A2 is generally associated with higher replication kinetics and more cytopathic effects earlier in infection when compared to other "laboratory" or clinical isolates [42,81-83]. It has been hypothesized that this may be due to a long history of passage-based adaptation in these cell lines [82]. The flexibility and ease by which A2 is able to replicate efficiently in a variety of cell platforms has also led many to believe that the virus utilizes a wide array of different receptors and attachment factors, including heparin sulfate and nucleolin [38,82]. While no significant morphological differences in virion structure or organization were observed between $A 2$ and a clinical isolate (A/TN/12/11-19), studies have reported that RSV A2 exhibits less thermal stability and potentially less pre-fusion F availability when compared to strain A2-line19F, further implicating that appreciable differences in stability and antigenicity may exist at a molecular level, even between similar strains $[14,42,84]$.

A key factor in the use of A2 in RSV research has been the establishment of two separate reverse genetics platforms based on the A2 genetic background. In 1995, the first reverse genetics system for RSV was developed through the co-transfection of a plasmid encoding the antigenome, along with supplementary plasmids expressing N, P, M2-1, and L proteins [16]. While this initial system was not very efficient, it did yield a platform to recover mutant infectious viruses and opened the door to the development of some of the first recombinant live-attenuated vaccines based on the A2 genetic background. In 2012, a similar reverse genetics platform was developed which utilized a bacterial artificial chromosome (BAC) for expression of the antigenome and was associated with more efficient virus recovery [15]. While the 1995 system was initially based on the A2 genetic background, the 2012 system was initially engineered to generate an A2-line19F virus. Studies comparing A2 and A2-line19F showed that the F protein of strain Line19 (see discussion below) was associated with more pathogenesis in mice when compared to strain A2 [83].

In summary, A2 continues to be a prototypic RSV strain and has been used extensively as a reverse genetics platform for the development of the majority of live-attenuated vaccine candidates to date. The strain is a key system for the study of RSV structure and has played a key role in elucidating immune responses in animal models to RSV infection [79].

\subsection{RSV Line 19 and A2-line19F}

Line 19 is an RSV subtype A virus that was first isolated from an infant with respiratory illness at the University of Michigan Hospital in 1967 and initially expanded in WI-38 cells [85]. However, subsequent studies of genomic differences between the Line 19 and Long strains have suggested that Line 19 may be a Long strain, mouse-adapted through serial intracranial inoculations in suckling mice generated in the same laboratory [73,79]. The pathogenesis of Line 19 infection in mice is distinct and different from other common strains such as A2 and Long. Infections in mice with strain Line 19 are biased towards a more $\mathrm{T}_{\mathrm{H}}$ 2-type antiviral response, with increased goblet cell expansion and elevated IL-13 and MUC5AC levels when compared to the $\mathrm{T}_{\mathrm{H}} 1$ responses associated with $\mathrm{A} 2$ and Long [86,87]. Compared to strain A2, Line 19 is also associated with lower overall titers in both HEp-2 cells and in mice in vivo [86]. A follow-up study using a recombinant A2-line19F virus (A2 expressing the F protein of Line 19) showed that the fusion protein of strain Line 19 was genetically unique and responsible for the differential immunopathology observed between the strains [83]. Regardless of its origin, strain Line 19 and a related strain, A2-line19F, have been established as important mouse models of pulmonary pathophysiology and immunologic responses. 


\section{4. $\mathrm{RSV}$ CH-18537}

CH-18537 is a RSV subtype B virus that was first isolated from a throat swab of a child with upper respiratory disease in 1962. The virus initially expanded in Wistar 26 cells [66]. Early studies in the 1960s established that $\mathrm{CH}-18537$ differed in antigenicity from the other contemporary isolates at the time [66]. Since these initial studies, $\mathrm{CH}-18537$ has been established as a common prototype RSV-B strain for genetic studies and continues to be used for evaluating antigenicity and genetic diversity [75,88-92].

\subsection{RSV Memphis-37}

The Memphis-37 strain is an RSV subtype A virus isolated as a nasal aspirate in 2001 from a 4-month-old African American male child with bronchiolitis [93]. The initial isolate was plaque purified and expanded as a GMP-lot in FDA-approved Vero cells for use in human clinical trials. Memphis-37 has been used to study RSV pathogenesis, the dynamics of immunologic responses to infection in healthy immunocompetent adults, and as a platform for testing inhibitors, vaccines, and therapeutics for RSV infection [94-97]. Intranasal inoculation of neonatal lambs with Memphis-37 has been shown to better reflect the pathogenesis and immune responses seen in humans when compared to other animal models [98]. Memphis-37 remains a primary model to study RSV pathogenesis and immunologic responses in humans.

\section{Contemporary RSV Strains, Pathogenesis, and Viral Evolution}

\subsection{The Genetics and Evolution of RSV Clinical Isolates}

Contemporary RSV clinical isolates are initially classified into either RSV-A or RSV-B subgroups, then often further classified into one of a rapidly growing number of genotypes [49,50,53,56,99]. Different genotypes are known to co-circulate during RSV seasons and genotypic dominance can vary based on the year and location [99,100]. Epidemiological studies often reveal genetic (and sometimes phenotypic) variance between isolates of the same subgroup and genotype [101]. The continual emergence of new strains and the identification of new genotypes highlights the ongoing evolution of the virus worldwide.

In the last 20 years, there have been two new emergent genotypes which have each taken precedence: ON1 and BA. The BA genotype emerged in samples obtained in Buenos Aires in 1999. These viruses exhibited a 60-nucleotide duplication within a hypervariable region in the G gene of RSV-B and within a few years became the predominant form of RSV-B detected worldwide [50,102-105]. Analysis of BA strains in vitro has shown that the G duplication impacts both viral attachment and replication, providing a fitness advantage over viruses lacking the duplication [58]. In parallel to the emergence of the G duplication in RSV-B strains, the more recent emergence and predominance of the RSV-A ON1 genotype over NA1 (its precursor lineage lacking the G duplication) has been well-noted and described [55,106,107]. During the RSV season of 2010-2011 in Ontario, Canada, a novel RSV genotype (ON1) containing a 72-nucleotide duplication in the C-terminal region of RSV $G$ was identified, which resulted in up to seven potential additional O-glycosylation sites within the protein. Similar to the BA genotype, the ON1 genotype quickly become common worldwide among RSV-A isolates $[56,108,109]$. Several recent groups have started describing mutations in RSV G which result in premature stop codons and deletions of the ON1 and BA genotypes [110]. These studies may indicate a growing level of immunity within some populations.

Analysis of the RSV F and G of recent isolates from 2015-2017 in the United States has shown not only that changes in RSV G were continuing to occur, but also changes in known antigenic sites in RSV $\mathrm{F}$ [109]. Recent analysis of isolates in Kenya has shown that adaptive amino acid changes are also being detected in other viral genes, including the viral polymerase (L) and M2-1 proteins [111]. A recent study from Lebanon has identified two additional RSV-A genotype variants (LBA1 and LBA2), but has also indicated a selection of variants with increased resistance to palivizumab, the only available 
prophylaxis option worldwide for RSV [112]. While nearly all studies evaluating recent clinical isolates have focused on genetic variations (rather than phenotypic differences), these viruses are known to differ appreciably in genetic sequence from current laboratory strains. Several studies have been performed to determine the relative mutation rates of RSV strains and have shown rates ranging from $10^{-3}$ to $10^{-4}$ nucleotide substitutions/site/year, depending upon the location and strain $[49,50,113,114]$. These data strongly suggest that evolutionary pressures are continuing to drive RSV evolution and potentially push modern circulating RSV strains further from the common laboratory strains isolated during 1950s and 1960s. We performed a phylogenetic analysis of RSV G gene sequences, comparing common laboratory strains and contemporary clinical isolates (Figure 2). From our analysis, and those performed by others, laboratory strains tend to cluster out and separate from contemporary clinical isolates, indicating that the viruses have likely evolved not only in genetic space, but potentially also in phenotype $[49,50,53,57]$.

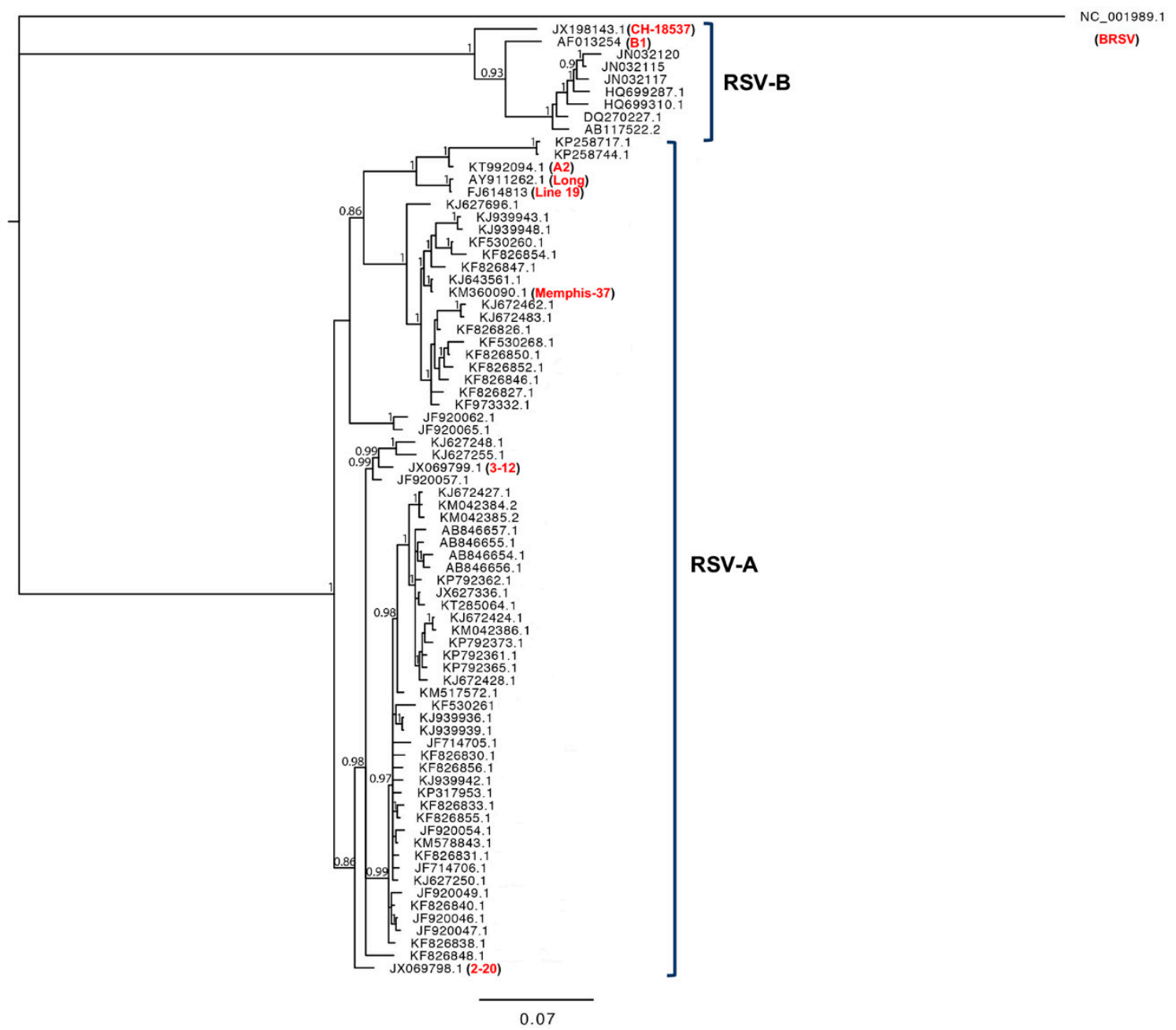

Figure 2. Phylogenetic analysis of an alignment of the RSV G gene sequences of common laboratory strains (identified in red) and contemporary clinical RSV-A and RSV-B isolates. A Bayesian inference of phylogenetic relationships between RSV G nucleotide sequences is shown. The phylogenetic outgroup was bovine RSV (BRSV). Numbers on branches are estimates for PPs (posterior probabilities) from the Bayesian inference (only numbers higher than 0.8 are shown). Common laboratory RSV-A strains A2, Long, Line 19, and Memphis (which are described in Section 2), as well as strains A2001/2-20, and A2001/3-12 (which have been more recently isolated and used to study RSV pathogenesis) are shown for phylogenetic comparison. Common laboratory RSV-B strains CH-18537 and B1 are also shown for comparison. 


\subsection{Disease, Pathogenesis, and Cytopathology among Clinical Isolates}

Numerous recent studies have surveyed clinical isolates obtained from sites around the world. From these multiyear studies, both the RSV-A and RSV-B strains co-circulate, with the dominance of strains varying over time [115-117]. However, RSV-A infections appear more frequent and appear to be associated with higher transmissibility than RSV-B [118-120]. The persistence of both of these distinct groups may explain the ability of previously infected individuals to remain susceptible to RSV infections [121]. While several studies have evaluated the disease potential of obtained RSV clinical isolates, the relationships and extent of variation, with regards to genetic sequences, genotypes, and clinical severities, remain unclear [122]. Confounding these issues, several multiyear studies have indicated significant phenotypic differences among the surveyed clinical isolates, while other studies have reported that no significant differences were observed [115-117,122-125]. Furthermore, very few studies have begun to evaluate the replication and pathophysiology of clinical isolates. The ambiguity in available clinical data, along with a lack of replication and pathophysiology data highlights an extensive need for understanding the current biology of circulating strains of RSV.

The limited studies that have begun to evaluate clinical strain differences, both in vitro and in vivo, have highlighted significant differences among strains, even within the same genotype grouping. In vitro models of infection have historically relied upon infections in continuous cell lines including HEp-2, A549, BEAS-2B, and Vero cells, however recent studies have demonstrated that these cell lines fail to recapitulate the native architecture of the airway epithelium and may bias the entry, spread, and infectivity of RSV [126-129]. A study using primary pediatric bronchial epithelial cells (PBECs) investigated whether the replication and cytopathology of prototypic laboratory strain A2 was representative of a panel of four recent clinical isolates. In this study, Villenave et al. demonstrated that A2 exhibits markedly different cytopathology, viral titers, and cytokine secretion than the clinical isolates surveyed [82]. Hypersecretion of mucus is a hallmark of severe neonatal RSV infections and is associated with higher disease potential in the lower respiratory tract [130]. In another study by Stokes et al., an analysis of a panel of six clinical isolates demonstrated significant differences among strains in disease severity, lung IL-13 cytokine production, and mucus production during infections in mice [81]. As previously described, studies have shown that the $G$ duplications associated with the ON1 and BA genotypes may confer increased fitness, both in vitro and in vivo, over those lacking these modifications, yet none of the prototypic laboratory strains express these important genetic variations. Collectively, these studies appear to suggest that conventional laboratory strains of RSV may not best represent the biology and pathology of clinical isolates circulating today.

\section{Summary and Future Implications for Vaccine Design}

As reviewed here, advances in our understanding of the biology of RSV continue to be driven through the extensive study of a limited number of prototypic laboratory strains. These studies have made great progress towards establishing the basis for current vaccine design efforts. However, while distinct differences have been observed (Table 1), far less is known on whether these "laboratory" models of RSV and contemporary clinical isolates differ significantly in infectivity, replication, or cytopathology. Extensive efforts are currently underway, by a multitude of groups, to develop effective vaccines for RSV. It remains unclear how well these candidate platforms will perform in providing broadly neutralizing coverage to circulating clinical isolates today and the near future. More effort should be afforded to the study of more recent isolates and to identify how these viruses fundamentally differ from the laboratory strains that have been characterized in the past. Understanding the extent of variations in genetics and phenotypes among RSV strains will inform better design of future vaccine constructs while also providing a more detailed picture of the landscape of RSV disease and pathogenesis in human populations today. 
Table 1. Comparative summary of laboratory and clinical isolates reviewed. The genetic type and common characteristics and applications are provided for each strain (or group).

\begin{tabular}{|c|c|c|}
\hline Virus Strain & Type and Designation & Characteristics and Applications \\
\hline Long & $\begin{array}{l}\text { RSV-A (Laboratory } \\
\text { Strain) }\end{array}$ & $\begin{array}{ll}\text { - } & \text { Isolated in } 1956 \\
\text { - } & \text { Primarily used today in studies of antigenicity } \\
\text { - } & \text { Prototypic RSV-A model }\end{array}$ \\
\hline A2 & $\begin{array}{l}\text { RSV-A (Laboratory } \\
\text { Strain) }\end{array}$ & $\begin{array}{l}\text { - } \quad \text { Isolated in } 1961 \\
\text { - } \quad \text { Most well-studied strain in use today; a prototypic RSV-A model } \\
\text { - } \quad \text { Higher replication kinetics in vitro compared to other strains } \\
\text { - } \quad \text { Mild cytopathology in animal models compared to other strains } \\
\text { - } \quad \text { Most commonly employed reverse genetics system } \\
\text { - } \quad \text { Most common strain used in live-attenuated vaccine preparations }\end{array}$ \\
\hline $\begin{array}{l}\text { Line } \\
\text { 19/A2-line19F }\end{array}$ & $\begin{array}{l}\text { RSV-A (Laboratory } \\
\text { Strain) }\end{array}$ & $\begin{array}{l}\text { - } \quad \text { Isolated in } 1967 \text { (A2-line19F synthesized in 2009) } \\
\text { - } \quad \text { Primarily used in pathogenesis and immunology studies } \\
\text { - } \quad \text { Lower viral load, but more severe pathophysiology in } \\
\text { animal models } \\
\text { - } \quad \text { Exhibits enhanced thermal stability compared to other strains }\end{array}$ \\
\hline CH 18537 & $\begin{array}{l}\text { RSV-B (Laboratory } \\
\text { Strain) }\end{array}$ & $\begin{array}{ll}\text { - } & \text { Isolated in } 1962 \\
\text { - } & \text { Primarily used in antigenicity studies } \\
\text { - } & \text { Prototypic RSV-B model }\end{array}$ \\
\hline Memphis-37 & $\begin{array}{l}\text { RSV-A (Laboratory } \\
\text { Strain) }\end{array}$ & $\begin{array}{ll}\text { - } & \text { Isolated in } 2001 \\
\text { - } & \text { Produced as a GMP lot for clinical studies } \\
\text { - } & \text { Primarily used in human pathogenesis and challenge studies }\end{array}$ \\
\hline Clinical Isolates & $\begin{array}{l}\text { RSV-A and RSV-B } \\
\text { Isolates }\end{array}$ & $\begin{array}{l}\text { - Vary significantly in genetic diversity and differ from conventional } \\
\text { laboratory strains } \\
\text { Most studies to date have focused on genetic variations } \\
\text { and epidemiology } \\
\text { Many circulating types today exhibit a G protein duplication (ON1 } \\
\text { and BA genotypes) } \\
\text { Limited pathogenesis studies suggest variations in cytopathology } \\
\text { and pathogenesis between isolates }\end{array}$ \\
\hline
\end{tabular}

Author Contributions: M.C.P., S.M.C., and C.C.S. were directly involved in the writing and editing of this review. K.G.S. conceptualized and performed the phylogenetic analysis as well as provided editing and writing support. All four authors have read this manuscript and approve it for submission.

Acknowledgments: We acknowledge Sean Berthrong for his guidance and helpful discussions pertaining to the organization and direction of this review. We also acknowledge Butler University Department of Biological Sciences and the Holcomb Awards Committee for their funding and logistical support of our research.

Conflicts of Interest: The authors of this manuscript declare no conflicts of interest.

\section{References}

1. Nair, H.; Simoes, E.A.; Rudan, I.; Gessner, B.D.; Azziz-Baumgartner, E.; Zhang, J.S.F.; Feikin, D.R.; A Mackenzie, G.; Moiïsi, J.C.; Roca, A.; et al. Global and regional burden of hospital admissions for severe acute lower respiratory infections in young children in 2010: A systematic analysis. Lancet 2013, 381, 1380-1390. [CrossRef]

2. Mazur, N.; Higgins, D.; Nunes, M.C.; Melero, J.A.; Langedijk, A.C.; Horsley, N.; Buchholz, U.J.; Openshaw, P.J.; McLellan, J.S.; Englund, J.A.; et al. The respiratory syncytial virus vaccine landscape: Lessons from the graveyard and promising candidates. Lancet Infect Dis. 2018, 18, e295-e311. [CrossRef]

3. Thompson, W.W.; Shay, D.K.; Weintraub, E.; Brammer, L.; Cox, N.; Anderson, L.J.; Fukuda, K. Mortality Associated with Influenza and Respiratory Syncytial Virus in the United States. JAMA 2003, 289, 179-186. [CrossRef]

4. $\quad$ Dowell, S.F.; Anderson, L.J.; Gary, H.E.; Erdman, D.D.; Plouffe, J.F.; File, T.M.; Marston, B.J.; Breiman, R.F. Respiratory Syncytial Virus Is an Important Cause of Community-Acquired Lower Respiratory Infection among Hospitalized Adults. J. Infect. Dis. 1996, 174, 456-462. [CrossRef] 
5. Walsh, E.E.; Peterson, D.R.; Falsey, A.R. Is Clinical Recognition of Respiratory Syncytial Virus Infection in Hospitalized Elderly and High-Risk Adults Possible? J. Infect. Dis. 2007, 195, 1046-1051. [CrossRef] [PubMed]

6. Falsey, A.R.; Hennessey, P.A.; Formica, M.A.; Cox, C.; Walsh, E.E. Respiratory Syncytial Virus Infection in Elderly and High-Risk Adults. N. Engl. J. Med. 2005, 352, 1749-1759. [CrossRef]

7. Shi, T.; McAllister, D.A.; O’Brien, K.L.; Simões, E.A.F.; Madhi, S.A.; Gessner, B.D.; Polack, F.P.; Balsells, E.; Acacio, S.; Aguayo, C.; et al. Global, regional, and national disease burden estimates of acute lower respiratory infections due to respiratory syncytial virus in young children in 2015: A systematic review and modelling study. Lancet 2017, 390, 946-958. [CrossRef]

8. Miyairi, I.; DeVincenzo, J.P. Human Genetic Factors and Respiratory Syncytial Virus Disease Severity. Clin. Microbiol. Rev. 2008, 21, 686-703. [CrossRef]

9. McIntosh, K.; Kurachek, S.C.; Cairns, L.M.; Burns, J.C.; Goodspeed, B. Treatment of respiratory viral infection in an immunodeficient infant with ribavirin aerosol. Am. J. Dis. Child. 1984, 138, 305-308. [CrossRef]

10. Macdonald, N.E.; Hall, C.B.; Suffin, S.C.; Alexson, C.; Harris, P.J.; Manning, J.A. Respiratory Syncytial Viral Infection in Infants with Congenital Heart Disease. N. Engl. J. Med. 1982, 307, 397-400. [CrossRef] [PubMed]

11. Cunningham, C.K.; McMillan, J.A.; Gross, S.J. Rehospitalization for respiratory illness in infants of less than 32 weeks' gestation. PEDIATRICS 1991, 88, 527-532. [PubMed]

12. Berkovich, $\mathrm{S}$. Acute respiratory illness in the premature nursery associated with respiratory syncytial virus infections. Pediatrics 1964, 34, 753-760. [PubMed]

13. Collins, P.L.; Melero, J.A. Progress in understanding and controlling respiratory syncytial virus: Still crazy after all these years. Virus Res. 2011, 162, 80-99. [CrossRef]

14. Ke, Z.; Dillard, R.S.; Chirkova, T.; Leon, F.; Stobart, C.C.; Hampton, C.M.; Strauss, J.D.; Rajan, D.; Rostad, C.A.; Taylor, J.V.; et al. The Morphology and Assembly of Respiratory Syncytial Virus Revealed by Cryo-Electron Tomography. Viruses 2018, 10, 446. [CrossRef] [PubMed]

15. Hotard, A.L.; Shaikh, F.Y.; Lee, S.; Yan, D.; Teng, M.N.; Plemper, R.K.; Crowe, J.E.; Moore, M.L.; Lopez-Ona, A. A Stabilized Respiratory Syncytial Virus Reverse Genetics System Amenable to Recombination Mediated Mutagenesis. Virology 2012, 434, 129-136. [CrossRef]

16. Collins, P.L.; Hill, M.G.; Camargo, E.; Grosfeld, H.; Chanock, R.M.; Murphy, B.R. Production of infectious human respiratory syncytial virus from cloned cDNA confirms an essential role for the transcription elongation factor from the 5' proximal open reading frame of the M2 mRNA in gene expression and provides a capability for vaccine development. Proc. Natl. Acad. Sci. USA 1995, 92, 11563-11567.

17. Bitko, V.; Shulyayeva, O.; Mazumder, B.; Musiyenko, A.; Ramaswamy, M.; Look, D.C.; Barik, S. Nonstructural proteins of respiratory syncytial virus suppress premature apoptosis by an NF-kB-dependent, interferon-independent mechanism and facilitate virus growth. J. Virol. 2007, 81, 1786-1795. [CrossRef]

18. Swedan, S.; Musiyenko, A.; Barik, S. Respiratory Syncytial Virus Nonstructural Proteins Decrease Levels of Multiple Members of the Cellular Interferon Pathways. J. Virol. 2009, 83, 9682-9693. [CrossRef]

19. Spann, K.M.; Tran, K.C.; Collins, P.L. Effects of Nonstructural Proteins NS1 and NS2 of Human Respiratory Syncytial Virus on Interferon Regulatory Factor 3, NF-kB, and Proinflammatory Cytokines. J. Virol. 2005, 79, 5353-5362. [CrossRef]

20. Lo, M.S.; Brazas, R.M.; Holtzman, M.J. Respiratory Syncytial Virus Nonstructural Proteins NS1 and NS2 Mediate Inhibition of Stat2 Expression and $\alpha / \beta$ Interferon Responsiveness. J. Virol. 2005, 79, 9315-9319. [CrossRef] [PubMed]

21. Teng, M.N.; Whitehead, S.S.; Collins, P.L. Contribution of the Respiratory Syncytial Virus G Glycoprotein and Its Secreted and Membrane-Bound Forms to Virus Replication In Vitro and In Vivo. Virology 2001, 289, 283-296. [CrossRef]

22. Sastre, P.; Melero, J.A.; Garcia-Barreno, B.; Palomo, C. Comparison of affinity chromatography and adsorption to vaccinia virus recombinant infected cells for depletion of antibodies directed against respiratory syncytial virus glycoproteins present in a human immunoglobulin preparation. J. Med. Virol. 2005, 76, 248-255. [CrossRef]

23. Cortjens, B.; Yasuda, E.; Yu, X.; Wagner, K.; Claassen, Y.B.; Bakker, A.Q.; Van Woensel, J.B.M.; Beaumont, T. Broadly Reactive Anti-Respiratory Syncytial Virus G Antibodies from Exposed Individuals Effectively Inhibit Infection of Primary Airway Epithelial Cells. J. Virol. 2017, 91, e02357-16. [CrossRef] 
24. Ngwuta, J.O.; Chen, M.; Modjarrad, K.; Joyce, M.G.; Kanekiyo, M.; Kumar, A.; Yassine, H.M.; Moin, S.M.; Killikelly, A.M.; Chuang, G.-Y.; et al. Prefusion F-specific antibodies determine the magnitude of RSV neutralizing activity in human sera. Sci. Transl. Med. 2015, 7, 309ra162. [CrossRef]

25. Levine, S.; Klaiber-Franco, R.; Paradiso, P.R. Demonstration that Glycoprotein G Is the Attachment Protein of Respiratory Syncytial Virus. J. Virol. 1987, 68, 2521-2524. [CrossRef] [PubMed]

26. Hendricks, D.A.; Baradaran, K.; McIntosh, K.; Patterson, J.L. Appearance of a Soluble Form of the G Protein of Respiratory Syncytial Virus in Fluids of Infected Cells. J. Virol. 1987, 68, 1705-1714. [CrossRef] [PubMed]

27. Roberts, S.R.; Lichtenstein, D.; Ball, L.A.; Wertz, G.W. The membrane-associated and secreted forms of the respiratory syncytial virus attachment glycoprotein $\mathrm{G}$ are synthesized from alternative initiation codons. J. Virol. 1994, 68, 4538-4546. [PubMed]

28. Kwilas, S.; Liesman, R.M.; Zhang, L.; Walsh, E.; Pickles, R.J.; Peeples, M.E. Respiratory Syncytial Virus Grown in Vero Cells Contains a Truncated Attachment Protein That Alters Its Infectivity and Dependence on Glycosaminoglycans. J. Virol. 2009, 83, 10710-10718. [CrossRef]

29. Melero, J.A.; Mas, V.; McLellan, J.S. Structural, antigenic and immunogenic features of respiratory syncytial virus glycoproteins relevant for vaccine development. Vaccine 2017, 35, 461-468. [CrossRef]

30. Johnson, P.R.; Spriggs, M.K.; Olmsted, R.A.; Collins, P.L. The G glycoprotein of human respiratory syncytial viruses of subgroups A and B: Extensive sequence divergence between antigenically related proteins. Proc. Natl. Acad. Sci. USA 1987, 84, 5625-5629. [CrossRef]

31. Collins, P.L.; Mottet, G. Oligomerization and post-translational processing of glycoprotein G of human respiratory syncytial virus: Altered O-glycosylation in the presence of brefeldin A. J. Virol. 1992, 73, 849-863. [CrossRef] [PubMed]

32. Satake, M.; Coligan, J.E.; Elango, N.; Norrby, E.; Venkatesan, S. Respiratory syncytial virus envelope glycoprotein (G) has a novel structure. Nucleic Acids Res. 1985, 13, 7795-7812. [CrossRef] [PubMed]

33. McLellan, J.S.; Ray, W.C.; Peeples, M.E. Structure and function of respiratory syncytial virus surface glycoproteins. Curr. Top Microbiol. Immunol. 2013, 372, 83-104. [CrossRef] [PubMed]

34. Tripp, R.A.; Jones, L.P.; Haynes, L.M.; Zheng, H.; Murphy, P.M.; Anderson, L.J. CX3C chemokine mimicry by respiratory syncytial virus $\mathrm{G}$ glycoprotein. Nat. Immunol. 2001, 2, 732-738. [CrossRef]

35. Hickling, T.P.; Malhotra, R.; Bright, H.; McDowell, W.; Blair, E.D.; Sim, R.B. Lung Surfactant Protein A Provides a Route of Entry for Respiratory Syncytial Virus into Host Cells. Viral. Immunol. 2000, 13, 125-135. [CrossRef] [PubMed]

36. Barr, F.E.; Pedigo, H.; Johnson, T.R.; Shepherd, V.L. Surfactant Protein-A Enhances Uptake of Respiratory Syncytial Virus by Monocytes and U937 Macrophages. Am. J. Respir. Cell Mol. Boil. 2000, 23, 586-592. [CrossRef] [PubMed]

37. Malhotra, R.; Ward, M.; Bright, H.; Priest, R.; Foster, M.R.; Hurle, M.; Blair, E.; Bird, M. Isolation and characterisation of potential respiratory syncytial virus receptor(s) on epithelial cells. Microbes Infect. 2003, 5, 123-133. [CrossRef]

38. Feldman, S.A.; Audet, S.; Beeler, J.A. The Fusion Glycoprotein of Human Respiratory Syncytial Virus Facilitates Virus Attachment and Infectivity via an Interaction with Cellular Heparan Sulfate. J. Virol. 2000, 74, 6442-6447. [CrossRef] [PubMed]

39. Chirkova, T.; Stobart, C.C.; Hartert, T.V.; Lin, S.; Gaston, K.A.; Anderson, L.J.; Oomens, A.G.P.; Boyoglu-Barnum, S.; Moore, M.L.; Ziady, A.G.; et al. CX3CR1 is an important surface molecule for respiratory syncytial virus infection in human airway epithelial cells. J. Gen. Virol. 2015, 96, 2543-2556. [CrossRef]

40. Meng, J.; Hotard, A.L.; Currier, M.G.; Lee, S.; Stobart, C.C.; Moore, M.L. Respiratory Syncytial Virus Attachment Glycoprotein Contribution to Infection Depends on the Specific Fusion Protein. J. Virol. 2016, 90, 245-253. [CrossRef]

41. McLellan, J.S.; Chen, M.; Leung, S.; Graepel, K.W.; Du, X.; Yang, Y.; Zhou, T.; Baxa, U.; Yasuda, E.; Beaumont, T.; et al. Structure of RSV Fusion Glycoprotein Trimer Bound to a Prefusion-Specific Neutralizing Antibody. Science 2013, 340, 1113-1117. [CrossRef] [PubMed]

42. Stobart, C.C.; Rostad, C.A.; Ke, Z.; Dillard, R.S.; Hampton, C.M.; Strauss, J.D.; Yi, H.; Hotard, A.L.; Meng, J.; Pickles, R.J.; et al. A live RSV vaccine with engineered thermostability is immunogenic in cotton rats despite high attenuation. Nat. Commun. 2016, 7, 13916. [CrossRef] 
43. Tayyari, F.; Marchant, D.; Moraes, T.J.; Duan, W.; Mastrangelo, P.; Hegele, R.G. Identification of nucleolin as a cellular receptor for human respiratory syncytial virus. Nat. Med. 2011, 17, 1132-1135. [CrossRef] [PubMed]

44. Villenave, R.; Nguyen, M.T.; Hammonds, J.; Sakamoto, K.; Lee, S.; Meng, J.; Currier, M.G.; Stobart, C.C.; Hotard, A.L.; Pretto, C.D.; et al. EGFR Interacts with the Fusion Protein of Respiratory Syncytial Virus Strain 2-20 and Mediates Infection and Mucin Expression. PLOS Pathog. 2016, 12, e1005622.

45. Battles, M.B.; McLellan, J.S. Respiratory syncytial virus entry and how to block it. Nat. Rev. Microbiol. 2019, 17, 233-245. [CrossRef] [PubMed]

46. McLellan, J.S.; Chen, M.; Joyce, M.G.; Sastry, M.; Stewart-Jones, G.B.E.; Yang, Y.; Zhang, B.; Chen, L.; Srivatsan, S.; Zheng, A.; et al. Structure-Based Design of a Fusion Glycoprotein Vaccine for Respiratory Syncytial Virus. Science 2013, 342, 592-598. [CrossRef]

47. Karron, R.A.; Buchholz, U.J.; Collins, P.L. Live-Attenuated Respiratory Syncytial Virus Vaccines; Springer Nature: Berlin, Germany, 2013; Volume 372, pp. 259-284.

48. Mufson, M.A.; Orvell, C.; Rafnar, B.; Norrby, E. Two Distinct Subtypes of Human Respiratory Syncytial Virus. J. Virol. 1985, 66, 2111-2124. [CrossRef]

49. Zlateva, K.T.; Lemey, P.; Vandamme, A.-M.; Van Ranst, M. Molecular Evolution and Circulation Patterns of Human Respiratory Syncytial Virus Subgroup A: Positively Selected Sites in the Attachment G Glycoprotein. J. Virol. 2004, 78, 4675-4683. [CrossRef]

50. Zlateva, K.T.; Lemey, P.; Moës, E.; Vandamme, A.-M.; Van Ranst, M. Genetic Variability and Molecular Evolution of the Human Respiratory Syncytial Virus Subgroup B Attachment G Protein. J. Virol. 2005, 79, 9157-9167. [CrossRef]

51. Sande, C.J.; Mutunga, M.N.; Medley, G.F.; Cane, P.A.; Nokes, D.J. Group- and genotype-specific neutralizing antibody responses against respiratory syncytial virus in infants and young children with severe pneumonia. J. Infect. Dis. 2013, 207, 489-492. [CrossRef] [PubMed]

52. Waris, M. Pattern of Respiratory Syncytial Virus Epidemics in Finland: Two-Year Cycles with Alternating Prevalence of Groups A and B. J. Infect. Dis. 1991, 163, 464-469. [CrossRef] [PubMed]

53. Trento, A.; Abrego, L.; Rodríguez-Fernández, R.; González-Sánchez, M.I.; González-Martínez, F.; Delfraro, A.; Pascale, J.M.; Arbiza, J.; Melero, J.A. Conservation of G-Protein Epitopes in Respiratory Syncytial Virus (Group A) Despite Broad Genetic Diversity: Is Antibody Selection Involved in Virus Evolution? J. Virol. 2015, 89, 7776-7785. [CrossRef] [PubMed]

54. Peret, T.C.; Golub, J.A.; Anderson, L.J.; Hall, C.B.; Schnabel, K.C. Circulation patterns of genetically distinct group A and B strains of human respiratory syncytial virus in a community. J. Virol. 1998, 79, 2221-2229. [CrossRef] [PubMed]

55. Agoti, C.N.; Otieno, J.R.; Gitahi, C.W.; Cane, P.A.; Nokes, D.J. Rapid Spread and Diversification of Respiratory Syncytial Virus Genotype ON1, Kenya. Emerg. Infect. Dis. 2014, 20, 950-959. [CrossRef] [PubMed]

56. Eshaghi, A.; Duvvuri, V.R.; Lai, R.; Nadarajah, J.T.; Li, A.; Patel, S.N.; Low, D.E.; Gubbay, J.B. Genetic Variability of Human Respiratory Syncytial Virus A Strains Circulating in Ontario: A Novel Genotype with a 72 Nucleotide G Gene Duplication. PLoS ONE 2012, 7, e32807. [CrossRef] [PubMed]

57. Trento, A.; Galiano, M.; Videla, C.; Carballal, G.; García-Barreno, B.; Melero, J.A.; Palomo, C. Major changes in the $\mathrm{G}$ protein of human respiratory syncytial virus isolates introduced by a duplication of 60 nucleotides. J. Virol. 2003, 84, 3115-3120. [CrossRef] [PubMed]

58. Hotard, A.L.; Laikhter, E.; Brooks, K.; Hartert, T.V.; Moore, M.L.; Lopez-Ona, A. Functional Analysis of the 60-Nucleotide Duplication in the Respiratory Syncytial Virus Buenos Aires Strain Attachment Glycoprotein. J. Virol. 2015, 89, 8258-8266. [CrossRef]

59. Botosso, V.F.; Zanotto, P.M.D.A.; Ueda, M.; Arruda, E.; Gilio, A.E.; Vieira, S.E.; Stewien, K.E.; Peret, T.C.T.; Jamal, L.F.; Pardini, M.I.D.M.C.; et al. Positive Selection Results in Frequent Reversible Amino Acid Replacements in the G Protein Gene of Human Respiratory Syncytial Virus. PLOS Pathog. 2009, 5, e1000254. [CrossRef]

60. Chanock, R.; Finberg, L. Recovery from infants with respiratory illness of a virus related to chimpanzee coryza agent (CCA). II. Epidemiologic aspects of infection in infants and young children. Am. J. Hyg. 1957, 66, 291-300.

61. Blount, R.E.; Morris, J.A.; Savage, R.E. Recovery of cytopathogenic agent from chimpanzees with coryza. Proc. Soc. Exp. Boil. Med. 1956, 92, 544-549. 
62. Chanock, R.; Finberg, L. Recovery from Infants with Respiratory Illness of A Virus Related To Chimpanzee Coryza Agent (Cca). Am. J. Epidemiol. 1957, 66, 281-290. [CrossRef]

63. Sullender, W.M. Respiratory Syncytial Virus Genetic and Antigenic Diversity. Clin. Microbiol. Rev. 2000, 13, 1-15. [CrossRef] [PubMed]

64. Johnson, K.M.; Chanock, R.M.; Rifkind, D.; Kravetz, H.M.; Knight, V. Respiratory syncytial virus. IV. Correlation of virus shedding, serologic response, and illness in adult volunteers. JAMA 1961, 176, 663-667.

65. Coates, H.V.; Forsyth, B.R.; Chanock, R.M. Biophysical Studies of Respiratory Syncytial Virus I. Density of Respiratory Syncytial Virus and Associated Complement-Fixing Antigens in a Cesium Chloride Density Gradient. J. Bacteriol. 1966, 91, 1263-1269.

66. Coates, H.V.; Kendrick, L.; Chanock, R.M. Antigenic Differences between Two Strains of Respiratory Syncytial Virus. Exp. Boil. Med. 1963, 112, 958-964. [CrossRef]

67. Suto, T.; Yano, N.; Ikeda, M.; Miyamoto, M.; Takai, S.; Shigeta, S.; Hinuma, Y.; Ishida, N. Respiratory Syncytial Virus Infection and Its Serologic Epidemiology. Am. J. Epidemiol. 1965, 82, 211-224. [CrossRef] [PubMed]

68. Doggett, J.E.; Taylor-Robinson, D. Serological studies with respiratory syncytial virus. Arch. Virol. 1965, 15, 601-608. [CrossRef]

69. Wulff, H.; Kidd, P.; Wenner, H.A. Respiratory Syncytial Virus: Observations on Antigenic Heterogeneity. Exp. Boil. Med. 1964, 115, 240-243. [CrossRef]

70. Norrby, E.; Marusyk, H.; Örvell, C. Morphogenesis of Respiratory Syncytial Virus in a Green Monkey Kidney Cell Line (Vero). J. Virol. 1970, 6, 237-242.

71. Prince, G.A.; Jenson, A.B.; Horswood, R.L.; Camargo, E.; Chanock, R.M. The pathogenesis of respiratory syncytial virus infection in cotton rats. Am. J. Pathol. 1978, 93, 771-791.

72. Prince, G.A.; Porter, D.D. The pathogenesis of respiratory syncytial virus infection in infant ferrets. Am. J. Pathol. 1976, 82, 339-352. [PubMed]

73. Cavallaro, J.J.; Maassab, H.F. Adaptation of Respiratory Syncytial (RS) Virus to Brain of Suckling Mice. Exp. Boil. Med. 1966, 121, 37-41. [CrossRef]

74. Hu, B.; Jiang, J.; Zhan, J.; Li, G.; Jiang, Y.; Guan, X.; Chen, Y.; Fang, Z. Development of a reverse genetics system for respiratory syncytial virus long strain and an immunogenicity study of the recombinant virus. Virol. J. 2014, 11, 142. [CrossRef]

75. Anderson, L.J.; Hierholzer, J.C.; Tsou, C.; Hendry, R.M.; Fernie, B.F.; Stone, Y.; McIntosh, K. Antigenic Characterization of Respiratory Syncytial Virus Strains with Monoclonal Antibodies. J. Infect. Dis. 1985, 151, 626-633. [CrossRef]

76. Rossey, I.; Sedeyn, K.; Wrapp, D.; Kanekiyo, M.; Chen, M.; Mas, V.; Spitaels, J.; Schepens, B.; Saelens, X.; Gilman, M.S.A.; et al. Potent single-domain antibodies that arrest respiratory syncytial virus fusion protein in its prefusion state. Nat. Commun. 2017, 8, 14158. [CrossRef]

77. Jones, H.G.; Ritschel, T.; Pascual, G.; Brakenhoff, J.P.J.; Keogh, E.; Furmanova-Hollenstein, P.; Lanckacker, E.; Wadia, J.S.; Gilman, M.S.A.; Williamson, R.A.; et al. Structural basis for recognition of the central conserved region of RSV G by neutralizing human antibodies. PLOS Pathog. 2018, 14, e1006935. [CrossRef]

78. Lewis, F.A.; Rae, M.L.; Lehmann, N.I.; Ferris, A.A. A syncytial virus associated with epidemic disease of the lower respiratory tract in infants and young children. Med. J. Aust. 1961, 48, 932-933.

79. Woolums, A.R.; Lee, S.; Moore, M.L. Animal Models of Respiratory Syncytial Virus Pathogenesis and Vaccine Development: Opportunities and Future Directions. RSV 2011. Available online: https://www.intechopen. com/download/pdf/24392 (accessed on 5 May 2019).

80. Moore, M.L.; Stokes, K.L.; Hartert, T.V. The impact of viral genotype on pathogenesis and disease severity: respiratory syncytial virus and human rhinoviruses. Curr. Opin. Immunol. 2013, 25, 761-768. [CrossRef] [PubMed]

81. Stokes, K.L.; Chi, M.H.; Sakamoto, K.; Newcomb, D.C.; Currier, M.G.; Huckabee, M.M.; Lee, S.; Goleniewska, K.; Pretto, C.; Williams, J.V.; et al. Differential Pathogenesis of Respiratory Syncytial Virus Clinical Isolates in BALB/c Mice. J. Virol. 2011, 85, 5782-5793. [CrossRef] [PubMed]

82. Villenave, R.; O’Donoghue, D.; Thavagnanam, S.; Touzelet, O.; Skibinski, G.; Heaney, L.G.; McKaigue, J.P.; Coyle, P.V.; Shields, M.D.; Power, U.F. Differential cytopathogenesis of respiratory syncytial virus prototypic and clinical isolates in primary pediatric bronchial epithelial cells. Virol. J. 2011, 8, 43. [CrossRef] 
83. Moore, M.L.; Chi, M.H.; Luongo, C.; Lukacs, N.W.; Polosukhin, V.V.; Huckabee, M.M.; Newcomb, D.C.; Buchholz, U.J.; Crowe, J.E.; Goleniewska, K.; et al. A Chimeric A2 Strain of Respiratory Syncytial Virus (RSV) with the Fusion Protein of RSV Strain Line 19 Exhibits Enhanced Viral Load, Mucus, and Airway Dysfunction. J. Virol. 2009, 83, 4185-4194. [CrossRef]

84. Rostad, C.A.; Stobart, C.C.; Todd, S.O.; Molina, S.A.; Lee, S.; Blanco, J.C.G.; Moore, M.L. Enhancing the Thermostability and Immunogenicity of a Respiratory Syncytial Virus (RSV) Live-Attenuated Vaccine by Incorporating Unique RSV Line19F Protein Residues. J. Virol. 2018, 92, e01568-17. [CrossRef] [PubMed]

85. Herlocher, M.; Ewasyshyn, M.; Sambhara, S.; Gharaee-Kermani, M.; Cho, D.; Lai, J.; Klein, M.; Maassab, H. Immunological properties of plaque purified strains of live attenuated respiratory syncytial virus (RSV) for human vaccine. Vaccine 1999, 17, 172-181. [CrossRef]

86. Lukacs, N.W.; Moore, M.L.; Rudd, B.D.; Berlin, A.A.; Collins, R.D.; Olson, S.J.; Ho, S.B.; Peebles, R.S. Differential Immune Responses and Pulmonary Pathophysiology Are Induced by Two Different Strains of Respiratory Syncytial Virus. Am. J. Pathol. 2006, 169, 977-986. [CrossRef]

87. Moore, M.L.; Peebles, R.S. Respiratory syncytial virus disease mechanisms implicated by human, animal model, and in vitro data facilitate vaccine strategies and new therapeutics. Pharmacol. Ther. 2006, 112, 405-424. [CrossRef] [PubMed]

88. Belshe, R.B.; Anderson, E.L.; Walsh, E.E. Immunogenicity of Purified F Glycoprotein of Respiratory Syncytial Virus: Clinical and Immune Responses to Subsequent Natural Infection in Children. J. Infect. Dis. 1993, 168, 1024-1029. [CrossRef]

89. Ghildyal, R.; Hogg, G.; Mills, J.; Meanger, J. Detection and subgrouping of respiratory syncytial virus directly from nasopharyngeal aspirates. Clin. Microbiol. Infect. 1997, 3, 120-123. [CrossRef]

90. Storch, G.A.; Park, C.S. Monoclonal antibodies demonstrate heterogeneity in the G glycoprotein of prototype strains and clinical isolates of respiratory syncytial virus. J. Med Virol. 1987, 22, 345-356. [CrossRef]

91. Lim, C.S.; Kumarasinghe, G.; Chow, V.T.K. Sequence and phylogenetic analysis of SH, G, and F genes and proteins of Human respiratory syncytial virus isolates from Singapore. Acta Virol. 2003, 47, 97-104.

92. Walsh, E.E.; Brandriss, M.W.; Schlesinger, J.J. Immunological Differences between the Envelope Glycoproteins of Two Strains of Human Respiratory Syncytial Virus. J. Virol. 1987, 68, 2169-2176. [CrossRef]

93. Kim, Y.-I.; DeVincenzo, J.P.; Jones, B.G.; Rudraraju, R.; Harrison, L.; Meyers, R.; Cehelsky, J.; Álvarez, R.; Hurwitz, J.L. Respiratory Syncytial Virus Human Experimental Infection Model: Provenance, Production, and Sequence of Low-Passaged Memphis-37 Challenge Virus. PLoS ONE 2014, 9, 113100. [CrossRef] [PubMed]

94. DeVincenzo, J.P.; Wilkinson, T.; Vaishnaw, A.; Cehelsky, J.; Meyers, R.; Nochur, S.; Harrison, L.; Meeking, P.; Mann, A.; Moane, E.; et al. Viral Load Drives Disease in Humans Experimentally Infected with Respiratory Syncytial Virus. Am. J. Respir. Crit. Care Med. 2010, 182, 1305-1314. [CrossRef] [PubMed]

95. Bagga, B.; Harrison, L.; Roddam, P.; DeVincenzo, J. Unrecognized prolonged viral replication in the pathogenesis of human RSV infection. J. Clin. Virol. 2018, 106, 1-6. [CrossRef]

96. DeVincenzo, J.; Lambkin-Williams, R.; Wilkinson, T.; Cehelsky, J.; Nochur, S.; Walsh, E.; Meyers, R.; Gollob, J.; Vaishnaw, A. A randomized, double-blind, placebo-controlled study of an RNAi-based therapy directed against respiratory syncytial virus. Proc. Natl. Acad. Sci. USA 2010, 107, 8800-8805. [CrossRef] [PubMed]

97. Eyles, J.E.; Johnson, J.E.; Megati, S.; Roopchand, V.; Cockle, P.J.; Weeratna, R.; Makinen, S.; Brown, T.P.; Lang, S.; Witko, S.E.; et al. Nonreplicating Vaccines Can Protect African Green Monkeys from the Memphis 37 Strain of Respiratory Syncytial Virus. J. Infect. Dis. 2013, 208, 319-329. [CrossRef]

98. Larios Mora, A.; Detalle, L.; Van Geelen, A.; Davis, M.S.; Stohr, T.; Gallup, J.M.; Ackermann, M.R. Kinetics of Respiratory Syncytial Virus (RSV) Memphis Strain 37 (M37) Infection in the Respiratory Tract of Newborn Lambs as an RSV Infection Model for Human Infants. PLoS ONE 2015, 10, e0143580. [CrossRef]

99. Cui, G.; Zhu, R.; Qian, Y.; Deng, J.; Zhao, L.; Sun, Y.; Wang, F. Genetic Variation in Attachment Glycoprotein Genes of Human Respiratory Syncytial Virus Subgroups A and B in Children in Recent Five Consecutive Years. PLoS ONE 2013, 8, e75020. [CrossRef] [PubMed]

100. Pretorius, M.A.; Van Niekerk, S.; Tempia, S.; Moyes, J.; Cohen, C.; Madhi, S.A.; Venter, M. Replacement and Positive Evolution of Subtype A and B Respiratory Syncytial Virus G-Protein Genotypes From 1997-2012 in South Africa. J. Infect. Dis. 2013, 208, 227-237. [CrossRef]

101. Mufson, M.A.; Belshe, R.B.; Örvell, C.; Norrby, E. Respiratory Syncytial Virus Epidemics: Variable Dominance of Subgroups A and B Strains Among Children, 1981-1986. J. Infect. Dis. 1988, 157, 143-148. [CrossRef] 
102. Arnott, A.; Vong, S.; Mardy, S.; Chu, S.; Naughtin, M.; Sovann, L.; Buecher, C.; Beauté, J.; Rith, S.; Borand, L.; et al. A Study of the Genetic Variability of Human Respiratory Syncytial Virus (HRSV) in Cambodia Reveals the Existence of a New HRSV Group B Genotype. J. Clin. Microbiol. 2011, 49, 3504-3513. [CrossRef]

103. Dapat, I.C.; Shobugawa, Y.; Sano, Y.; Saito, R.; Sasaki, A.; Suzuki, Y.; Kumaki, A.; Zaraket, H.; Dapat, C.; Oguma, T.; et al. New Genotypes within Respiratory Syncytial Virus Group B Genotype BA in Niigata, Japan. J. Clin. Microbiol. 2010, 48, 3423-3427. [CrossRef]

104. Trento, A.; Viegas, M.; Galiano, M.; Videla, C.; Carballal, G.; Mistchenko, A.S.; Melero, J.A. Natural history of human respiratory syncytial virus inferred from phylogenetic analysis of the attachment $(\mathrm{G})$ glycoprotein with a 60-nucleotide duplication. J. Virol. 2006, 80, 975-984. [CrossRef] [PubMed]

105. Shobugawa, Y.; Saito, R.; Sano, Y.; Zaraket, H.; Suzuki, Y.; Kumaki, A.; Dapat, I.; Oguma, T.; Yamaguchi, M.; Suzuki, H. Emerging Genotypes of Human Respiratory Syncytial Virus Subgroup A among Patients in Japan. J. Clin. Microbiol. 2009, 47, 2475-2482. [CrossRef]

106. Tabatabai, J.; Prifert, C.; Pfeil, J.; Grulich-Henn, J.; Schnitzler, P. Novel Respiratory Syncytial Virus (RSV) Genotype ON1 Predominates in Germany during Winter Season 2012-13. PLoS ONE 2014, 9, 109191. [CrossRef]

107. Auksornkitti, V.; Kamprasert, N.; Thongkomplew, S.; Suwannakarn, K.; Theamboonlers, A.; Samransamruajkij, R.; Poovorawan, Y. Molecular characterization of human respiratory syncytial virus, 2010-2011: Identification of genotype ON1 and a new subgroup B genotype in Thailand. Arch. Virol. 2014, 159, 499-507. [CrossRef]

108. Khor, C.-S.; Sam, I.-C.; Hooi, P.-S.; Chan, Y.-F. Displacement of predominant respiratory syncytial virus genotypes in Malaysia between 1989 and 2011. Infect. Genet. Evol. 2013, 14, 357-360. [CrossRef] [PubMed]

109. Lu, B.; Liu, H.; Tabor, D.E.; Tovchigrechko, A.; Qi, Y.; Ruzin, A.; Esser, M.T.; Jin, H. Emergence of new antigenic epitopes in the glycoproteins of human respiratory syncytial virus collected from a US surveillance study, 2015-17. Sci. Rep. 2019, 9, 3898. [CrossRef]

110. Tabatabai, J.; Thielen, A.; Lehners, N.; Daeumer, M.; Schnitzler, P. Respiratory syncytial virus A in haematological patients with prolonged shedding: Premature stop codons and deletion of the genotype ON1 72-nucleotide-duplication in the attachment G gene. J. Clin. Virol. 2018, 98, 10-17. [CrossRef] [PubMed]

111. Otieno, J.R.; Kamau, E.M.; Oketch, J.W.; Ngoi, J.M.; Gichuki, A.M.; Binter, Š.; Otieno, G.P.; Ngama, M.; Agoti, C.N.; Cane, P.A.; Kellam, P. Whole genome analysis of local Kenyan and global sequences unravels the epidemiological and molecular evolutionary dynamics of RSV genotype ON1 strains. Virus Evol. 2018, 4. [CrossRef] [PubMed]

112. Abou-El-Hassan, H.; Massaad, E.; Soudani, N.; Assaf-Casals, A.; Shaker, R.; Khoury, M.L.; Ghanem, S.; Karam, M.; Andary, R.; Saito, R.; et al. Detection of ON1 and novel genotypes of human respiratory syncytial virus and emergence of palivizumab resistance in Lebanon. PLoS ONE 2019, 14, e0212687. [CrossRef] [PubMed]

113. Haider, M.S.H.; Khan, W.H.; Deeba, F.; Ali, S.; Ahmed, A.; Naqvi, I.H.; Dohare, R.; Alsenaidy, H.A.; Alsenaidy, A.M.; Broor, S.; et al. BA9 lineage of respiratory syncytial virus from across the globe and its evolutionary dynamics. PLoS ONE 2018, 13, e0193525. [CrossRef]

114. Di Giallonardo, F.; Kok, J.; Fernandez, M.; Carter, I.; Geoghegan, J.; Dwyer, D.; Holmes, E.; Eden, J.S. Evolution of Human Respiratory Syncytial Virus (RSV) over Multiple Seasons in New South Wales, Australia. Viruses 2018, 10, 476. [CrossRef]

115. Fodha, I.; Vabret, A.; Ghedira, L.; Seboui, H.; Chouchane, S.; Dewar, J.; Gueddiche, N.; Trabelsi, A.; Boujaafar, N.; Freymuth, F. Respiratory syncytial virus infections in hospitalized infants: Association between viral load, virus subgroup, and disease severity. J. Med Virol. 2007, 79, 1951-1958. [CrossRef]

116. Otieno, J.R.; Kamau, E.M.; Agoti, C.N.; Lewa, C.; Otieno, G.; Bett, A.; Ngama, M.; Cane, P.A.; Nokes, D.J. Spread and Evolution of Respiratory Syncytial Virus A Genotype ON1, Coastal Kenya, 2010-2015. Emerg. Infect. Dis. 2017, 23, 264-271. [CrossRef]

117. Esposito, S.; Piralla, A.; Zampiero, A.; Bianchini, S.; Di Pietro, G.; Scala, A.; Pinzani, R.; Fossali, E.; Baldanti, F.; Principi, N. Characteristics and Their Clinical Relevance of Respiratory Syncytial Virus Types and Genotypes Circulating in Northern Italy in Five Consecutive Winter Seasons. PLoS ONE 2015, 10, 0129369. [CrossRef]

118. White, L.J.; Waris, M.; Cane, P.A.; Nokes, D.J.; Medley, G.F.; Medley, G. The transmission dynamics of groups A and B human respiratory syncytial virus (hRSV) in England \& Wales and Finland: seasonality and cross-protection. Epidemiol. Infect. 2005, 133, 279-289. 
119. Vandini, S.; Biagi, C.; Lanari, M. Respiratory Syncytial Virus: The Influence of Serotype and Genotype Variability on Clinical Course of Infection. Int. J. Mol. Sci. 2017, 18, 1717. [CrossRef]

120. Hall, C.B.; Walsh, E.E.; Schnabel, K.C.; Long, C.E.; McConnochie, K.M.; Hildreth, S.W.; Anderson, L.J. Occurrence of Groups A and B of Respiratory Syncytial Virus over 15 Years: Associated Epidemiologic and Clinical Characteristics in Hospitalized and Ambulatory Children. J. Infect. Dis. 1990, 162, 1283-1290. [CrossRef]

121. Agoti, C.N.; Mwihuri, A.G.; Sande, C.J.; Onyango, C.O.; Medley, G.F.; Cane, P.A.; Nokes, D.J. Genetic Relatedness of Infecting and Reinfecting Respiratory Syncytial Virus Strains Identified in a Birth Cohort from Rural Kenya. J. Infect. Dis. 2012, 206, 1532-1541. [CrossRef]

122. Rodriguez-Fernandez, R.; Tapia, L.I.; Yang, C.-F.; Torres, J.P.; Chavez-Bueno, S.; Garcia, C.; Jaramillo, L.M.; Moore-Clingenpeel, M.; Jafri, H.S.; Peeples, M.E.; et al. Respiratory Syncytial Virus Genotypes, Host Immune Profiles, and Disease Severity in Young Children Hospitalized with Bronchiolitis. J. Infect. Dis. 2017, 217, 24-34. [CrossRef]

123. Yoshihara, K.; Le, M.N.; Okamoto, M.; Wadagni, A.C.A.; Nguyen, H.A.; Toizumi, M.; Pham, E.; Suzuki, M.; Nguyen, A.T.T.; Oshitani, H.; et al. Association of RSV-A ON1 genotype with Increased Pediatric Acute Lower Respiratory Tract Infection in Vietnam. Sci. Rep. 2016, 6, 27856. [CrossRef]

124. Laham, F.R.; Mansbach, J.M.; Piedra, P.A.; Hasegawa, K.; Sullivan, A.F.; Espinola, J.A.; Camargo, C.A. Clinical Profiles of Respiratory Syncytial Virus Subtypes A and B among Children Hospitalized with Bronchiolitis. Pediatr. Infect. J. 2017, 36, 808-810. [CrossRef]

125. Martinello, R.A.; Chen, M.D.; Weibel, C.; Kahn, J.S. Correlation between Respiratory Syncytial Virus Genotype and Severity of Illness. J. Infect. Dis. 2002, 186, 839-842. [CrossRef]

126. Zhang, L.; Peeples, M.E.; Boucher, R.C.; Collins, P.L.; Pickles, R.J. Respiratory Syncytial Virus Infection of Human Airway Epithelial Cells Is Polarized, Specific to Ciliated Cells, and without Obvious Cytopathology. J. Virol. 2002, 76, 5654-5666. [CrossRef]

127. Groves, H.E.; Guo-Parke, H.; Broadbent, L.; Shields, M.D.; Power, U.F. Characterisation of morphological differences in well-differentiated nasal epithelial cell cultures from preterm and term infants at birth and one-year. PLoS ONE 2018, 13, e0201328. [CrossRef] [PubMed]

128. Villenave, R.; Thavagnanam, S.; Sarlang, S.; Parker, J.; Douglas, I.; Skibinski, G.; Heaney, L.G.; McKaigue, J.P.; Coyle, P.V.; Shields, M.D.; et al. In vitro modeling of respiratory syncytial virus infection of pediatric bronchial epithelium, the primary target of infection in vivo. Proc. Natl. Acad. Sci. USA 2012, 109, 5040-5045. [CrossRef] [PubMed]

129. Gray, T.E.; Guzman, K.; Davis, C.W.; Abdullah, L.H.; Nettesheim, P. Mucociliary differentiation of serially passaged normal human tracheobronchial epithelial cells. Am. J. Respir. Cell Mol. Boil. 1996, 14, 104-112. [CrossRef] [PubMed]

130. Drajac, C.; Laubreton, D.; Riffault, S.; Descamps, D. Pulmonary Susceptibility of Neonates to Respiratory Syncytial Virus Infection: A Problem of Innate Immunity? J. Immunol. 2017, 2017, 1-13. [CrossRef] 